\title{
Exploring Barriers of M-Commerce Adoption in SMEs in the UK: Developing a Framework using ISM
}

\author{
Nripendra P. Rana* \\ School of Management \\ Swansea University Bay Campus \\ Fabian Way, Swansea, SA1 8EN, UK \\ Daniel J. Barnard \\ School of Management \\ Swansea University Bay Campus \\ Fabian Way, Swansea, SA1 8EN, UK \\ Abdullah M.A. Baabdullah \\ King Abdulaziz University \\ Jeddah 21589, Saudi Arabia \\ Daniel Rees \\ School of Management \\ Swansea University Bay Campus \\ Fabian Way, Swansea, SA1 8EN, UK \\ Sian Roderick \\ School of Management \\ Swansea University Bay Campus \\ Fabian Way, Swansea, SA1 8EN, UK
}

*Corresponding Author

\begin{abstract}
In the modern business era, mobile commerce (m-commerce) is changing the way the business is conducted using the Internet. However, the prominence of m-commerce among small and medium-sized enterprises (SMEs) in the UK is minimal. The purpose of this study is to evaluate the existing literature and to extend the research surrounding the barriers that prevent the adoption of m-commerce amongst SMEs. The study uses an Interpretive Structural Modelling (ISM) and MICMAC approach for guiding and helping managers of SMEs. Data was collected from an expert participant group each of whom had extensive knowledge of m-commerce. The findings represent the unstable nature of variables in the context of their impact on each other, their relationships, and themselves. The listed factors in the proposed framework and the interrelationships between them highlight the multidimensional element of m-commerce adoption prevention. This observation proves criticality of analysing data as a collective entity rather than viewing the barriers in isolation. The findings also indicated 'perceived risk' being a key barrier that demonstrates how personal opinions of the concept of adoption can have a great significance on the outcome and whether other variables will come into effect.
\end{abstract}

Keywords: M-commerce, Adoption, Barriers, SMEs, ISM, Wales 


\section{Introduction}

The concept of mobile commerce (hereafter, m-commerce) has grown exponentially within business in the last decade and the rise of technology, specifically smartphones and tablet devices, complement its growth (Einav, Levin, Popov \& Sundaresan, 2014). M-commerce facilitates purchases and other transactions using wireless networks over the Internet and its unique benefits allow businesses to offer extended value to its customers (Sumita and Yoshii, 2010). These customers are also able to conveniently shop for products anywhere at any time using a personal device, providing an Internet connection is available. M-commerce is likely to proliferate even further in the coming years as it strengthens the connection between users and businesses. Businesses are able to see the potential and understand that the vast penetration rates of smartphone users lends to the fundamental need for adoption. In short, the use of technology and mobile devices has been engrained in everyday tasks and the dependence on these devices is only increasing (Kourouthanassis \& Giaglis, 2012). Businesses are able to exploit this phenomenon and profit from increased market share and new revenue streams. Adoption for SMEs however, is not a smooth and easily successful process and as the current literature (Alkhunaizan \& Love 2012; Yadev, Sharma \& Tarhini, 2016) suggests, there are a considerable number of barriers that might hinder adoption.

Although the literature surrounding e-commerce is extensive (Abebe, 2014; Sotiriadis \& Van Zyl, 2014), m-commerce has lacked the attention from researchers and academics alike, resulting in less information and literature for smaller businesses to learn from (Dahlberg, Guo \& Ondrus, 2015; Hussain, Mkpojiogu \& Kamal, 2016; Ngai \& Gunasekaran, 2007). The current literature suggests how important m-commerce can become within organisations. Managers nevertheless are not provided with any frameworks on how to adopt the technology or to inform them of the barriers. This research will allow the reader, or more specifically an SME manager, to obtain a clearer insight to the advantages of m-commerce and the barriers that may hinder the adoption of such technologies. The research data will provide the input for the interpretive structural modelling (ISM) methodology from which a framework that visibly presents the barriers in a multi-levelled system is created. The framework will bridge a gap in current research by investigating the relationships between small businesses and mcommerce with the aim of simplifying the process of adoption.

The lack of research into SME m-commerce adoption is the problem area that this research study will address. SMEs struggle to meet the needs of the consumers and managers can often be put off due to the pressures of the expectations placed on them (Saguy, 2011). High costs, perceived risk and external pressure are some of the barriers that the managers frequently encounter and how to possibly overcome these obstacles is still a challenge for them. During the course of the study, a range of areas within the topic will be discussed that build an understanding of what m-commerce is and the effects it has on business and the possibilities it can provide for SMEs. The literature discusses accessibility, variables and growth of m-commerce as well as the barriers that prevent adoption. They all combine to provide the desired understanding to learn from the resulting framework.

The study will discuss the m-commerce adoption barriers from existing literature and explain how they are part of the methodology. The ISM process will generate the results via the stepby-step process. An analysis of the results and in depth discussion will highlight the findings 
and the key areas that are most relevant to SME managers and the adoption process. This information will centre on the ISM model developed from the results. The conclusion section will bring together the main points raised in the discussion and any limitations will be identified. Areas for future research will be suggested. An appendix (see Appendix [A]), providing detail of the questionnaire will precede the reference section at the end of the study.

\section{M-Commerce and the UK Context}

\subsection{Defining m-commerce}

M-commerce for the most part is a clear and concise concept. The term 'm-commerce' itself derives from the earlier term 'e-commerce'. However, Paavilainen, (2002) believes the term is misleading to an extent as the business models and value chain are totally different from ecommerce. The consensus here is that m-commerce is not a truncated form of e-commerce but is a new and innovative way of conducting transactions regardless of location. Sissing, Dlamini \& Johnston, (2017) disagree that m-commerce is dissimilar to e-commerce by stating 'it is similar to e-commerce except that the transactions by m-commerce are through a mobile device via wireless connections'. Descriptions of m-commerce are likely to vary to a degree between researchers, business managers, customers and industry experts alike. Due to its innovativeness and striking opportunities, its prominence is gaining much attention. Even though the definitions of m-commerce are somewhat different, the core principle is that a consumer can perform transactions over a wireless network from any location with Internet access.

\subsection{Growth of m-commerce}

It is evident by just evaluating todays current business environment and online consumer activity that m-commerce has grown exponentially in the last decade or so (Rahimi et al., 2014). Sumita and Yoshii (2010) believe that consumers have a more flexible access to the Internet due to the availability of a new generation of mobile devices (mobile phones and tablets etc.). They go on to say that e-commerce is in the process of being converted to mcommerce while stressing that e-commerce is still a vital means of exploiting the advantages of the Internet. Einav, Levin, Popov \& Sundaresan (2014) use eBay as evidence of the large and rapid growth of m-commerce from a consumer perspective. In 2008, mobile-originated transactions on eBay were at zero, in June 2013, more than one third of eBay's active users were, in any given month, mobile adopters. In only a five year period, one of the world's largest online marketplaces has seen a dramatic shift in how users are conducting transactions. The two research papers discussed (Einav, Levin, Popov \& Sundaresan, 2014; Sumita and Yoshii (2010) illustrate how significant m-commerce is for business growth, in terms of exploiting the rise of smartphone penetration among consumers and the popularity of their use in commercial activity.

\subsection{M-commerce accessibility}


It would be forgivable to assume that most businesses in the UK, regardless of size, would have the required technology and resources available to them to provide m-commerce services to their customers. Technologically developed countries such as the UK have the telecommunications infrastructure available and have integrated m-commerce within their business processes. To add further, it is evident that m-commerce services available to smartphone users in the UK are continuously increasing. However, m-commerce is not viable without a mobile device that can handle digital data connected to digital communications infrastructures (Harris, Rettie \& Kwan, 2005).

\subsection{Value proposition of m-commerce}

Studies have highlighted that m-commerce delivers specific benefits that engender new product development, markets, communication channels, revenue streams and new services over and above those in the traditional e-commerce setting (Mennecke and Strader, 2003). There are clear advantages of adopting mobile technologies for commerce purposes when comparing the hardware required for the use of e-commerce and m-commerce, a PC and handheld mobile device respectively. A mobile device is also cheaper to invest in and the learning curve of these devices is faster than any other technology (Anckar \& D’Incau, 2002). The innovation and diversification of the general use of mobile devices is a motivating factor for many businesses to consider the development of their own m-commerce infrastructure. Developed countries of late show high rates of mobile phone adoption and with that comes a transformation in the way in which the devices are used. The added value that m-commerce can deliver to organisations, demonstrates the criticality of adoption within businesses and potential of expanded customer segments.

\section{Literature Review}

This section discusses the relevant literature surrounding barriers of m-commerce. With the use of academic sources, the ten barriers of adoption are identified and analysed. For extracting the appropriate barriers for the m-commerce adoption, we used keywords such as 'm-commerce' or 'mobile commerce', and 'adoption' with 'SMEs' or 'organisation' or 'firm' in their different combinations within Google Scholar. We found 32 studies highlighting ten key barriers for m-commerce adoption for SMEs.

\subsection{Perceived cost}

A critical factor for a business when adopting or implementing a new technology is the cost. How much will it cost the business to develop and install new technologies? How long will it take to recover the costs associated? Furthermore, regardless of how the organisations perceive the benefits, if the business cannot afford to adopt m-commerce then the benefits will not be realised. Bouwman, Carlsson, Molina-Castillo \& Walden (2007) believe price to be one of the major barriers to adoption; Pagani (2004) also states that cost is an important factor. Studies suggest that price is one of the barriers of adoption that would prevent consumers and businesses alike from using m-commerce as a means of shopping and data gathering and a way of conducting business respectively. If consumers are priced out of 
adopting m-commerce then businesses will not have a sufficient number of users for $\mathrm{m}$ commerce to be worthwhile. Vrechoupoulos et al. (2003) discusses the high price for mobile device access for consumers. This supports the theory that consumer access to m-commerce with regard to price is important to understand before a business makes a decision in undertaking the implementation of m-commerce. Prices of smartphones however are decreasing. At the start of the decade (2010), the average smartphone selling price worldwide was \$336.8, falling to \$245.1 in 2017. By 2019, the average selling price is set to fall even further to $\$ 214.7$ (Statista, 2017). The figures suggest that $\mathrm{m}$-commerce is gradually becoming more affordable for consumers worldwide and therefore the likelihood for success in the m-commerce industry for businesses, especially SMEs, is greater now than in the past.

\subsection{Perceived risk}

The risk associated with adopting m-commerce for a business closely relates to the perceived cost. If the organisation decides to invest in m-commerce development, then the business case for this investment must take account of the risks to the business (Wu \& Wang, 2017). Organisations must ensure that any investment decision takes account of the whole life costs including maintenance. Perceived risk can take shape in many forms, it does not just relate to financial risk. Expanding a business so it integrates with a vast network of connections with millions of devices all sharing information will always incur an element of concern with respect to wireless privacy issues. Djenouri \& Badache (2004) describe threats to the network as 'attacks'. These attacks intentionally cause damage to the network, disrupting and/or infiltrating individual user's devices or affecting business processes. Managers with the task of adopting m-commerce must seriously evaluate the threats that could possibly arise from wireless networks. As technology improves however, suppliers of such services are striving for better security and will assure m-commerce adopters that the information sent on their networks is protected from hackers (Pathan, Lee \& Hong, 2006).

\subsection{Lack of technology knowledge}

Smaller businesses are less likely to possess the required technology that enables mcommerce adoption. Technology penetration level as a whole is lower than those businesses already proficient in e-commerce (Hunaiti et al. 2009). Businesses deficient in e-commerce technology, could struggle to develop an m-commerce infrastructure due to insufficient knowledge in this area. Estrin, Foreman \& Garcia (2003) indicate that a lack of expertise among employees of SMEs may lead to the downfall of m-commerce processes as managers often spend their time on activities that affect the bottom line rather than spending a sufficient amount of time on strategic decisions involving m-commerce. The alternative, for managers

with adequate knowledge, would be to manage the process themselves; limiting the time they have in managing other areas of the business. Bouwman, Carlsson, Molina-Castillo \& Walden (2007) uses the term 'cognitive accessibility' to describe an employee's understanding of how systems work technically and how they master new technologies. Without employees' complete understanding of the infrastructure and processes involved it will be difficult to achieve the objectives the business sets itself, therefore limiting mcommerce effectiveness. 


\subsection{Changes in business strategy and processes}

In order to successfully implement m-commerce, entire business strategies may need to be altered or completely transformed in order to accommodate new technologies, processes and ways of working. Siau, Ee-Peng \& Shen (2001) state that many organisations need to be redesigned in order to stay competitive and realize genuine productivity benefits from mcommerce. Organisations can gain substantial benefits from m-commerce in the form of retailing, marketing, and in finance. Manufacturing firms are able to improve efficiency by reducing costs and streamlining operational processes (Kim, 2006). Changes to strategy and business processes that coincide with m-commerce implementation add complexity and cost, which for many business, especially SMEs, could prove to be too much. Some may simply not have the capacity to deal with all the aspects that m-commerce implementation entails.

\subsection{Customer trust and confidence}

The confidence of the customer, when using their mobile device to complete purchase transactions, could be considered a major stumbling block if measures are not taken by the SME to reassure them (Liébana-Cabanillas et al., 2017; Lin, 2011). The literature provides no definitive method to overcome customer confidence and trust issues however, Shao Yeh \& $\mathrm{Li}$, (2009) state that trust in m-commerce can be divided into two categories; trust in mobile technology and trust in mobile vendors. Siau, Ee-Peng \& Shen (2001) state that for customers to build trust they must be assured that their financial information is secure and wireless transactions are safe. Siau \& Shen (2003) agree that security is a major issue for customers and it is because of this issue that they question the integrity of Internet vendors. Furthermore, from an organisational point of view, as convenient as mobile devices are, their small screens, lower resolution displays and multifunction touch keypads make adequate interface development difficult. From the literature, it is clear that to be successful, SMEs must develop and maintain customer relationships with minimal direct interaction. This can be achieved by ensuring that the customer experience is convenient, easy, fast and secure.

\subsection{Unawareness of benefits}

The advantages and opportunities that m-commerce can provide for consumers and businesses alike are not always clear and many SMEs put themselves at a disadvantage by not implementing. M-commerce has evolved from the growth of mobile technology and in the absence of a clear understanding of benefits, it could be difficult for SME managers to fully appreciate the value that m-commerce can deliver. In relation, small businesses may not feel the need for an online presence or their business reach does not extend outside of their local area or region. Managers could become ignorant to the concept of online business, including m-commerce (Aburalob \& Kang, 2015). Managers risk missing crucial opportunities that are viable for their business if they took the time to build an understanding rather than eliminating the concept of m-commerce because of perceived risk.

\subsection{Inconvenience of use}


For the majority of SMEs, the adoption of m-commerce is a major process requiring significant financial and intellectual capital. It is this perception that leads to the belief that convenience must match the expenditure applied for it to be worth the implementation in the first place. Scupola (2003) found that, among SMEs, the perception of e-commerce is that it is a constant interruption and distraction, with far too much technology changes and junk emails etc. The practicality of adoption is questioned by Lane et al. (2004), especially the sale of goods over the Internet, although this has become more productive and convenient in recent years. Maintenance can also be viewed as too detrimental to a small business that cannot waste time in mastering the use of online technologies, but need to maintain a constant level of productivity.

\subsection{Lack of external pressure}

M-commerce adoption must be assessed before implementation both internally and externally. Internal benefits may be recognisable, but does the SMEs specific external environment necessarily require them to take on m-commerce? Looi (2003) expresses that lack of external pressure from suppliers can act as a barrier and therefore inhibit adoption. Taylor \& Murphy (2004) are specific in saying that small businesses are more likely to occupy small and clearly defined niche markets that do not require global connectivity. Pracey \& Cooper (2000) suggest that if the customer does not ask for the technology due to their locality then there will no reason to adopt it. Although all of the discussed literature is evaluating e-commerce, the same can be applied for m-commerce. If there is a lack of pressure from external sources then the implementation of e-commerce/m-commerce will waste money and time and ultimately become a redundant part of the business.

\subsection{Compatibility issues}

There are many reasons why SMEs are unable to pursue m-commerce. Olatokun \& Bankole (2017) explain that the firm's characteristic heavily influences the decision of adoption. The size, common practice, the nature of the industry they are in and the traditional way of doing business all inflict a significant impact on adoption of online technologies. Zaied (2012) in their study of e-commerce adoption in Egyptian SMEs uses difficulty in changing existing working procedures' as a barrier to summarise the internal difficulties of adoption. This relates to the previous section of literature review which details the changes in business strategy and processes although still relates to issues related to compatibility and fit because of the transformation that must occur for successful implementation. On the flip side, organisations with large amounts of data and transactions will more than likely adopt electronic commerce, either traditional e-commerce or m-commerce, to further streamline business processes and become more efficient (Thong \& Yap, 1995). From the literature it is evident that the internal nature of an SME is a major factor in decision making and can act as a deterrent of adoption.. SMEs that directly interact with customers, are less likely to adopt m-commerce technologies, however, SMEs can potentially realise enhanced benefits in the context of increased sales from a wider base of stakeholders. 


\subsection{Privacy and security issues}

In the early stages of commercial Internet use, many customers were wary of using their personal details online where information is transferred electronically. In particular, financial transactions generate significant concern among customers as it involves the use of their bank details in order to complete a transaction. Much like e-commerce, m-commerce works in a similar fashion where bank details are saved online and the user is never absolutely certain who has access to this sensitive data (Fang et al., 2017; Stead \& Gilbert, 2001). For SMEs this is a concern that must be addressed in order to reassure their customers that personal data is safe when they interact with the organisations m-commerce infrastructure. Online privacy and security issues do not stop at threats to the security of financial data. The use of the Internet with a mobile device leaves a larger footprint than the consumer initially believes (Chin et al., 2018). Stead \& Gilbert (2001) in their study of security issues within ecommerce conclude that some consumers feel they lose their sense of privacy when their personal information is gathered secretly and used to target them with personalised advertisements and other consumer specific marketing. Many online entities go as far as tracking a user across multiple websites by tracing their IP address. This is achieved with the use of a Cookie which will tailor the user's experience.(Kuehn, 2013). Table 1 presents the barriers for m-commerce adoption in the SMEs with the support of relevant literature.

Table 1. The barriers of m-commerce adoption in SMEs in the UK

\begin{tabular}{|c|c|c|c|}
\hline SL & Barriers & Implied Meaning & Studies \\
\hline 1 & Perceived cost & $\begin{array}{l}\text { The cost associated with the } \\
\text { implementation of m-commerce might be } \\
\text { too high and therefore prevent the } \\
\text { business from investing }\end{array}$ & $\begin{array}{l}\text { Bouwman et al. (2007), } \\
\text { Pagani (2004) }\end{array}$ \\
\hline 2 & Perceived risk & $\begin{array}{l}\text { Businesses want to predict the benefits of } \\
\text { m-commerce but cannot be certain, } \\
\text { therefore they must weigh up the costs } \\
\text { with the risk of failure }\end{array}$ & $\begin{array}{l}\text { Abualrob \& Kang (2015), } \\
\text { Wu \& Wang (2017) }\end{array}$ \\
\hline 3 & $\begin{array}{lr}\text { Lack of } & \text { technology } \\
\text { knowledge } & \end{array}$ & $\begin{array}{l}\text { Without understanding what m-commerce } \\
\text { is or how it works managers might decide } \\
\text { against adoption }\end{array}$ & $\begin{array}{l}\text { Estrin, Foreman \& Garcia } \\
\text { (2003), Hunaiti et al. (2009) }\end{array}$ \\
\hline 4 & $\begin{array}{l}\text { Forced changes to } \\
\text { business strategy }\end{array}$ & $\begin{array}{l}\text { Managers must decide whether adoption } \\
\text { will change how the business operates and } \\
\text { whether it is worth implementing }\end{array}$ & $\begin{array}{l}\text { Siau, Ee-Peng \& Shen } \\
(2001)\end{array}$ \\
\hline 5 & $\begin{array}{l}\text { Lack of customer trust } \\
\text { and confidence }\end{array}$ & $\begin{array}{l}\text { Current customers might not be familiar } \\
\text { with m-commerce and may avoid using it } \\
\text { if the business decides to adopt }\end{array}$ & Shao, Yeh \& Li (2009) \\
\hline 6 & Unawareness of benefits & $\begin{array}{l}\text { Not being aware of the benefits and } \\
\text { advantages of m-commerce will inhibit } \\
\text { managers from implementing the required } \\
\text { technology }\end{array}$ & Aburalob \& Kang (2015) \\
\hline 7 & Inconvenience of use & $\begin{array}{l}\text { Some managers may deem m-commerce } \\
\text { as too time consuming and not beneficial } \\
\text { for the business }\end{array}$ & $\begin{array}{l}\text { Lane et al. (2004), Scupola } \\
\text { (2003) }\end{array}$ \\
\hline 8 & Lack of external pressure & $\begin{array}{l}\text { Demand for m-commerce from customers } \\
\text { and suppliers alike may be minimal or } \\
\text { non-existent so adoption would be } \\
\text { pointless }\end{array}$ & $\begin{array}{l}\text { Pracey \& Cooper (2000), } \\
\text { Taylor \& Murphy (2004) }\end{array}$ \\
\hline 9 & Compatibility issues & $\begin{array}{l}\text { The current technology or operations } \\
\text { within the business might not compliment } \\
\text { m-commerce sufficiently }\end{array}$ & $\begin{array}{l}\text { Olatokun \& Bankole } \\
\text { (2017), Zaied (2012) }\end{array}$ \\
\hline
\end{tabular}




\begin{tabular}{|l|ll|l|l|ll|}
\hline 10 & $\begin{array}{l}\text { Privacy and security } \\
\text { issues }\end{array}$ & $\begin{array}{l}\text { Customers may not use an organisations } \\
\text { m-commerce services if they are sceptical } \\
\text { of the security of their private and } \\
\text { financial information }\end{array}$ & $\begin{array}{l}\text { Kuehn (2013), Stead \& } \\
\text { Gilbert (2001) }\end{array}$ & \& \\
\hline
\end{tabular}

\section{ISM Methodology and Process}

The research begins by gathering, interpreting and analysing the key perceptions of academics in the area of m-commerce. This information then forms the basis of the main barriers of adoption. This study utilises a mathematically derived method titled ISM, which enables the systematic representation of a complex problem or unrelated ideologies (Warfield, 1974). The entire process seeks to establish the most impactful m-commerce adoption barriers and present them in a multi-levelled model based on the opinions of SME managers, which prioritises the barriers for a clearer understanding for the SME manager.

The ten barriers listed in the previous section are utilised as the factors required for the implementation of the ISM method. The ISM process is used in this context to identify interdependencies between the set of barriers. The assessment of the type and extent of the barrier relationships was developed via the use of an expert participant group. Five expert SME managers were selected from a range of business sectors, where each manager either controls, or is responsible for business processes within their respective organisations.

The ISM process is a well-established method used to identify relationships among what usually are specific individual items that are of no particular relevance in isolation until they are grouped together to define a complex problem or issue. There may be a high number of factors that are considered to be the cause of a problem or issue but if they are analysed in isolation then the situation will be described far less accurately than it would be if the factors were linked through direct and indirect relationships. ISM has the ability to deliver a collective understanding and insight into a problem or issue (Jharkharia \& Shankar, 2005).

To be more specific, in its mechanical functions the ISM method, first proposed by Warfield (1974), is a complex system of equations that generates binary relation to convey interconnection. As previously stated ISM takes confused and non-associated factors and transforms them into practical, clearly defined models (Hughes, Dwivedi, Rana \& Simintiras, 2016). ISM is an established and widely implemented method within academic studies due to its success in identifying interrelations between elements of similar nature and indicating areas of influence among them to be subsequently portrayed in a final model. Therefore, ISM was deemed to be a suitable method to develop the required detailed understanding of causal factors that prevent adoption of m-commerce. We handed in the ISM-based questionnaire survey to the SME expert managers and they were briefed about how to fill in the ISM matrix. Identifying relationships, both direct and indirect creates a consensus of the factors taken from past literature. Singh, Garg \& Deshmukh (2007) used ISM to aid SMEs in strategic decisions by developing relationships between competitive factors. This serves as justification for the use of ISM as it motivates managers to review their perceived opinions and consider their decisions based on the links between key barriers. The current gap in the literature suggests it is unknown what connections these barriers have or whether there are 
any relationships between them. ISM will provide the means to achieve this by empirically analysing expert opinions.

The ISM process in this study is illustrated in Figure 1. It shows a step-by-step approach starting with the set of barriers from the literature review. The resulting assessments by the questionnaire participants of the contextual relationships between these barriers are displayed in a structural self-interaction matrix (SSIM). Four symbols are used to denote the directions of the relationships between the barriers, $\mathrm{V}, \mathrm{A}, \mathrm{X}$ and $\mathrm{O}$. The initial reachability matrix (IRM), is then prepared from the SSIM. The symbols are converted into binary matrix (see Table 3). The next step uses a set of rules to incorporate transitivity to the matrix which then creates the final reachability matrix (FRM). Transitivity of contextual relation in ISM that states if barrier A is related to barrier B and B is related to barrier C then A will essentially relate to $\mathrm{C}$. Progression of the FRM is continued by including level partitions where each barrier is subject to being put into reachability sets, antecedent sets and interaction sets. Sifting through the partition levels continues until the bottom level is reached of the ISM hierarchy.

The next step is to develop the canonical matrix of the FRM. This is achieved by clustering the variables into the levels from the previous step across the rows and columns of the FRM. The driving and dependence powers are established in this matrix. The transitive links are removed and the barriers are then represented in MICMAC (Matrics d'Impacts CroisesMultiplication Applique an Classment), the positioning on the digraph dependent on their level of driving and dependence power influence. The MICMAC is separated into four quadrants i.e. autonomous, dependent, linkage and driving. They each classify the variables by their positioning, which is determined by their driving and dependence power. Within this model the barriers are displayed according to their associated level from (a) Autonomous Barriers, to (b) Dependent Barriers, to (c) Linkage Barriers, to (d) Driving Barriers with links between the associated barriers. A final review of the model will check for any conceptual inconsistencies and adjustments can be made from there.

At Stage 3 of the ISM process model in Figure 1 is where the questionnaire gathers the opinions of the SME managers. The questionnaire includes a section where the participant answers questions about themselves and their business. This is done so there is a better knowledge of the participating business. Then they will rate each barrier by their perceived level of significance in a 5-point Likert scale, so it is clear how they perceive each barrier before completing the structural self-interaction matrix (SSIM). The questionnaire is featured in Appendix A for reference.

In summary, the data collected from the industry specific participants is analysed using ISM and presented in a clear and concise model using the interrelationship of barriers of mcommerce adoption of SMEs. With this knowledge, the managers will be able to analyse and prioritise each barrier of m-commerce adoption in SMEs and deal with them in order to succeed in adoption. More detail of the ISM is discussed further into the results and data analysis section along with a detailed discussion of the findings and what they entail for SME managers with regard to m-commerce adoption in the Discussion section. 


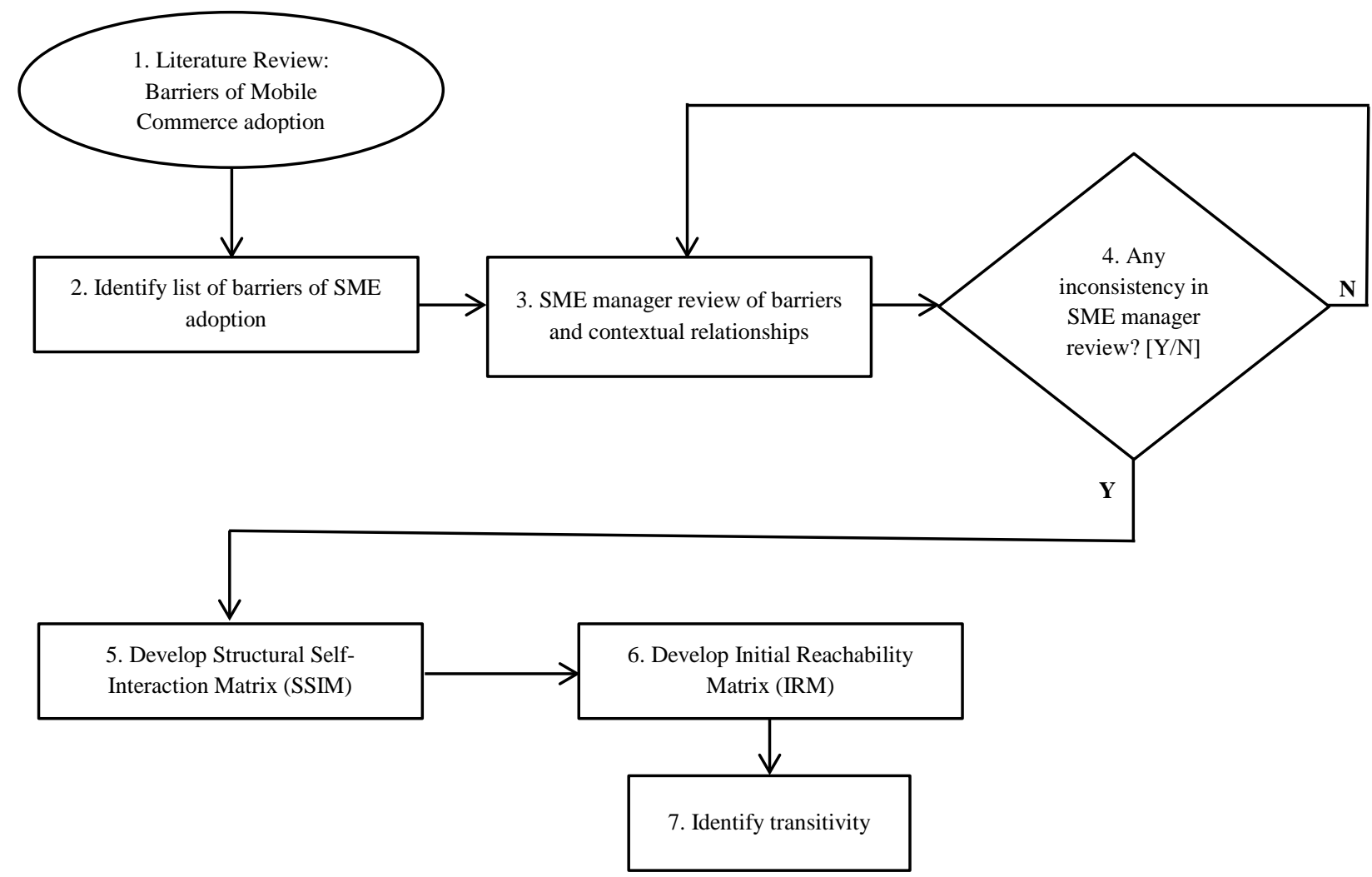




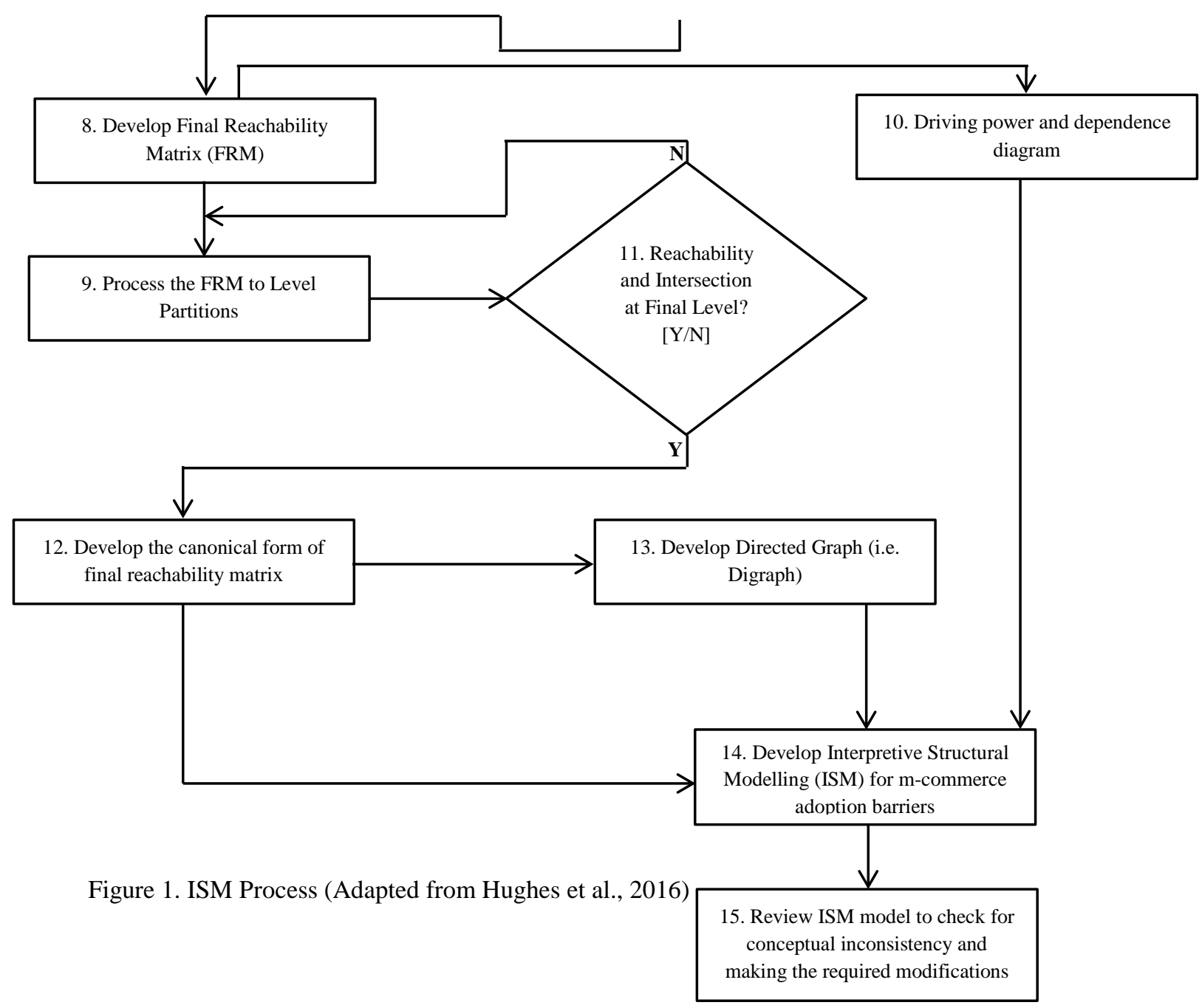

\section{Results and Data Analysis}

\subsection{Structural self-interaction matrix (SSIM)}

The group of participants analysed the variables that make up the matrix and attempt to identify any interrelationships between them based upon their own opinion and the constraints of the ISM ruling. The variables the participants analysed are: [1] Perceived cost, [2] Perceived risk, [3] Lack of technology knowledge, [4] Forced changes to business strategy, [5] Lack of customer trust and confidence, [6] Unawareness of benefits, [7] Inconvenience of use, [8] Lack of external pressure, [9] Compatibility issues, and [10] Privacy and security issues.

The relationships in this matrix derive from the context that a certain variable may affect another or vice versa, while other variables may affect each other equally and others may not affect each other at all. In order to achieve clarity and consistency between the perception of the relationships amongst each participant the terms, 'helps achieve' and 'influences' were used within the instructions of the questionnaire. The interactions between the variables are displayed in rows and columns marked $\mathrm{i}$ and $\mathrm{j}$ respectively. The SSIM is set out in Table 2 where the symbols of $\mathrm{V}, \mathrm{A}, \mathrm{X}$ and $\mathrm{O}$ represent the type of relationship between each factor 
(Al-Muftah et al., 2018; Janssen et al., 2018; Hughes et al., 2016; Mangla et al., 2018; Mishra et al., 2017; Dwivedi et al., 2017a).

$\mathrm{V}$ : variable i will help achieve or have influence on variable $\mathrm{j}$; A: variable $\mathrm{j}$ will help achieve or have influence on variable $\mathrm{i}$; $\mathrm{X}$ : variable $\mathrm{i}$ and variable $\mathrm{j}$ will help achieve or influence each other; $\mathrm{O}$ : variables $\mathrm{i}$ and $\mathrm{j}$ are not related.

To explain the formation of the SSIM in Table 2 an example can be extracted: The SME managers identified that 'Lack of technology knowledge' (3) helps achieve or has influence over 'Privacy and security issues' (10), therefore at the $\mathrm{i}, \mathrm{j}$ intersection of 3:10 in the matrix a $\mathrm{V}$ is inserted to represent this relationship. A is inserted in the intersection of 5:9 where 'Compatibility issues' (9) helps achieve or influences 'Lack of customer trust and confidence' (5). 'Forced changes to business strategy' (4) and 'Lack of customer trust and confidence' (5) are deemed to have no influence over each other so an $\mathrm{O}$ is inserted in the cell 4:5. Where there is an influence both ways between a pair of variables as 'Lack of technology knowledge' (3) and 'Unawareness of benefits' (6) there is an X in cell 3:6. The method is continued until all cells are completed. The empty cells in the matrix represent the area of replication where relationships are covered elsewhere.

Table 2. Structural self-interaction matrix
\begin{tabular}{|c|c|c|c|c|c|c|c|c|c|}
\hline i & 10 & 9 & 8 & 7 & 6 & 5 & 4 & 3 & 2 \\
\hline 1 & $\mathrm{~V}$ & $\mathrm{~V}$ & $\mathrm{~V}$ & $\mathrm{~A}$ & $\mathrm{~A}$ & $\mathrm{~V}$ & $\mathrm{~A}$ & $\mathrm{O}$ & $\mathrm{V}$ \\
\hline 2 & $\mathrm{~V}$ & $\mathrm{~V}$ & $\mathrm{~V}$ & $\mathrm{~V}$ & $\mathrm{~V}$ & $\mathrm{~V}$ & $\mathrm{~V}$ & $\mathrm{~V}$ & \\
\hline 3 & $\mathrm{~V}$ & $\mathrm{~V}$ & $\mathrm{O}$ & $\mathrm{V}$ & $\mathrm{X}$ & $\mathrm{V}$ & $\mathrm{O}$ & & \\
\hline 4 & $\mathrm{~V}$ & $\mathrm{~A}$ & $\mathrm{~V}$ & $\mathrm{~A}$ & $\mathrm{~A}$ & $\mathrm{O}$ & & & \\
\hline 5 & $\mathrm{~A}$ & $\mathrm{~A}$ & $\mathrm{~A}$ & $\mathrm{~A}$ & $\mathrm{~A}$ & & & & \\
\hline 6 & $\mathrm{~V}$ & $\mathrm{~V}$ & $\mathrm{~V}$ & $\mathrm{O}$ & & & & & \\
\hline 7 & $\mathrm{~V}$ & $\mathrm{~V}$ & $\mathrm{~V}$ & & & & & & \\
\hline 8 & $\mathrm{~V}$ & $\mathrm{~V}$ & & & & & & & \\
\hline 9 & $\mathrm{O}$ & & & & & & & & \\
\hline
\end{tabular}

[Legend: 1=Perceived cost, 2=Perceived risk, 3=Lack of technology knowledge, 4=Forced changes to business strategy, 5=Lack of customer trust and confidence, 6=Unawareness, 7=Inconvenience of use, 8=Lack of external pressure, 9=Compatibility issues, 10=Privacy and security issues]

\subsection{IRM and FRM}

The development of the Initial Reachability Matrix (IRM) is the next step in the ISM process followed by the development of the Final Reachability Matrix (FRM). The content of the SSIM is transformed into a binary format where the following rules dictate its conversion:

[1] if the (i, j) cell entry in the SSIM is V, then the equivalent ( $i, j$ ) entry in the IRM becomes 1 and the (j, i) cell entry becomes: 0 ;

[2] if the (i, j) cell entry in the SSIM is A, then the equivalent ( $i, j$ ) entry in the IRM becomes 0 and the $(\mathrm{j}, \mathrm{i})$ cell entry becomes 1 ;

[3] if the ( $i, j$ ) cell entry in the SSIM is $X$, then the equivalent ( $i, j$ ) entry in the IRM becomes 1 and the $(\mathrm{j}$, i) cell entry also becomes 1 ;

[4] if the (i, j) cell entry in the SSIM is $\mathrm{O}$, then the equivalent ( $\mathrm{i}, \mathrm{j}$ ) entry in the IRM becomes 0 and the $(\mathrm{j}, \mathrm{i})$ cell entry also becomes 0 ;

Table 3 illustrates the completed matrix whereby all cells have been converted to binary matrix by means of the preceding rules. 
Table 3. Initial reachability matrix

\begin{tabular}{|c|c|c|c|c|c|c|c|c|c|c|c|c|}
\hline Variables & 1 & 2 & 3 & 4 & 5 & 6 & 7 & 8 & 9 & 10 \\
\hline 1 & 1 & 1 & 0 & 0 & 1 & 0 & 0 & 1 & 1 & 1 \\
\hline 2 & 0 & 1 & 1 & 1 & 1 & 1 & 1 & 1 & 1 & 1 \\
\hline 3 & 0 & 0 & 1 & 0 & 1 & 1 & 1 & 0 & 1 & 1 \\
\hline 4 & 1 & 0 & 0 & 1 & 0 & 0 & 0 & 1 & 0 & 1 \\
\hline 5 & 0 & 0 & 0 & 0 & 1 & 0 & 0 & 0 & 0 & 0 \\
\hline 6 & 1 & 0 & 1 & 1 & 1 & 1 & 0 & 1 & 1 & 1 \\
\hline 7 & 1 & 0 & 0 & 1 & 1 & 0 & 1 & 1 & 1 & 1 \\
\hline 8 & 0 & 0 & 0 & 0 & 1 & 0 & 0 & 1 & 1 & 1 \\
\hline 9 & 0 & 0 & 0 & 1 & 1 & 0 & 0 & 0 & 1 & 0 \\
\hline 10 & 0 & 0 & 0 & 0 & 1 & 0 & 0 & 0 & 0 & 1 \\
\hline
\end{tabular}

[Legend: 1=Perceived cost, 2=Perceived risk, 3=Lack of technology knowledge, $4=$ Forced changes to business strategy, 5=Lack of customer trust and confidence, 6=Unawareness, 7=Inconvenience of use, 8=Lack of external pressure, 9=Compatibility issues, 10=Privacy and security issues]

Next the IRM is extended to include transitivity. The term transitive is used to identify when a relation exists between a first element and a second element and between the second and third element then a relationship holds between the first and third. Within the FRM, transitivity is denoted with a $1^{*}$.

If $A$ is linked to $B(A \rightarrow B)$ and $B$ is linked to $C(B \rightarrow C)$ then it can be said that there is a transitive relationship between $A$ and $C(A \rightarrow C)$. The approach used to identify transitivity outlined in equation (1) to populate the FRM is as follows:

Step 1: Start from row 1 of the IRM and work down to row n. Identify all instances of ' 1 ' in row $1(\mathrm{j})$ and note these to aid the next step. Ignore n:n references, e.g. 1:1.

Step 2: For each instance of a 0 across the full row (j), look down on the specific column (i) and reference against each previously noted instance of ' 1 ' from first row but now against the column.

Step 3: If a match is found in step 2, then convert any instances of 0 in above scenario to $1^{*}$ and continue to the next instance of 0 across the row (j). Continue with this method until the complete matrix is checked for transitivity (Hughes et al., 2016).

Table 4. Final reachability matrix

\begin{tabular}{|c|c|c|c|c|c|c|c|c|c|c|c|c|}
\hline Variables & 1 & 2 & 3 & 4 & 5 & 6 & 7 & 8 & 9 & 10 \\
\hline 1 & 1 & 1 & $1^{*}$ & $1^{*}$ & 1 & $1^{*}$ & $1^{*}$ & 1 & 1 & 1 \\
\hline 2 & $1^{*}$ & 1 & 1 & 1 & 1 & 1 & 1 & 1 & 1 & 1 \\
\hline 3 & $1^{*}$ & 0 & 1 & $1^{*}$ & 1 & 1 & 1 & $1^{*}$ & 1 & 1 \\
\hline 4 & 1 & $1^{*}$ & 0 & 1 & $1^{*}$ & 0 & 0 & 1 & $1^{*}$ & 1 \\
\hline 5 & 0 & 0 & 0 & 0 & 1 & 0 & 0 & 0 & 0 & 0 \\
\hline 6 & 1 & $1^{*}$ & 1 & 1 & 1 & 1 & $1^{*}$ & 1 & 1 & 1 \\
\hline 7 & 1 & $1^{*}$ & 0 & 1 & 1 & 0 & 1 & 1 & 1 & 1 \\
\hline 8 & 0 & 0 & 0 & $1^{*}$ & 1 & 0 & 0 & 1 & 1 & 1 \\
\hline 9 & $1^{*}$ & 0 & 0 & 1 & 1 & 0 & 0 & $1^{*}$ & 1 & $1^{*}$ \\
\hline 10 & 0 & 0 & 0 & 0 & 1 & 0 & 0 & 0 & 0 & 1 \\
\hline
\end{tabular}


[Legend: $1=$ Perceived cost, 2=Perceived risk, $3=$ Lack of technology knowledge, 4=Forced changes to business strategy, 5=Lack of customer trust and confidence, $6=$ Unawareness, $7=$ Inconvenience of use, $8=$ Lack of external pressure, $9=$ Compatibility issues, $10=$ Privacy and security issues]

\subsection{FRM partitioning}

The FRM matrix must now be partitioned by assessing the reachability and antecedent sets for each individual variable (Warfield, 1974). The reachability $\mathrm{R}(\mathrm{Pi})$ and antecedent $\mathrm{A}(\mathrm{Pi})$ sets need to be completed in the next step. The reachability set $\mathrm{R}(\mathrm{Pi})$ consists of the individual variable and the other variables in which it may help achieve. These are distinguished in Table 4 in the form of 1 and $1 *$ for each variable (i) across all rows (j). The antecedent $\mathrm{A}(\mathrm{Pi})$ set consists of the individual variable and the other variables that may help in achieving it. This is also highlighted in Table 4 by noting the instances of 1 and $1^{*}$ for the column (j) that corresponds with each variable (i). The intersection of these two sets $(\mathrm{R}(\mathrm{Pi}) \cap$ $\mathrm{A}(\mathrm{Pi}))$ is the final variable of the top-level partition matrix where the common variables between $\mathrm{R}(\mathrm{Pi})$ and $\mathrm{A}(\mathrm{Pi})$ are listed in the final column.

In the first level of partitioning (see Table 5), the top level of the ISM hierarchy is established where there is a match between the reachability $\mathrm{R}(\mathrm{Pi})$ and intersection $\mathrm{R}(\mathrm{Pi})$ \& $\mathrm{A}(\mathrm{Pi})$ sets. An ' $I$ ' will be inserted next to the appropriate variable where a match exists. In this instance the only matching variable in the first iteration of partitioning is Variable 5 ('Lack of customer trust and confidence'). As such, this variable does not help achieve any other variable at a higher level in the ISM model and features at the top of the model as the solitary barrier in Level I of the barriers of m-commerce adoption. The process is continued in Iteration II (Table 6), however in this iteration the variables outlined in Level I are removed. Iteration II now displays the matches between the reachability $\mathrm{R}(\mathrm{Pi})$ set and interaction $\mathrm{R}(\mathrm{Pi})$ \& $\mathrm{A}(\mathrm{Pi})$ set in the same manner as before, but without the previous matching variables from Iteration I. Again there is only one matching variable in the form of 'Privacy and security issues' (10) which will take its place in Level II of the ISM model hierarchy. The exact same steps are taken until all variables are consequently assigned to a level. In this study there are a total of six iterations, meaning there are six levels to the ISM model.

Table 5. Level partition - Iteration I

\begin{tabular}{|c|l|l|l|c|}
\hline P(i) & Reachability Set R(Pi) & Antecedent Set: A(Pi) & Intersection: R(Pi) \& A(Pi) & Level \\
\hline 1 & $1,2,3,4,5,6,7,8,9,10$ & $1,2,3,4,6,7,9$ & $1,2,3,4,6,7,9$ & \\
\hline 2 & $1,2,3,4,5,6,7,8,9,10$ & $1,2,4,6,7$ & $1,2,4,6,7$ & \\
\hline 3 & $1,3,4,5,6,7,8,9,10$ & $1,2,3,6$ & $1,3,6$ & \\
\hline 4 & $1,2,4,5,8,9,10$ & $1,2,3,4,6,7,8,9$ & $1,2,4,8,9$ & \\
\hline 5 & 5 & $1,2,3,4,5,6,7,8,9,10$ & 5 & I \\
\hline 6 & $1,2,3,4,5,6,7,8,9,10$ & $1,2,3,6$ & $1,2,3,6$ & \\
\hline 7 & $1,2,4,5,7,8,9,10$ & $1,2,3,6,7$ & $1,2,7$ & \\
\hline 8 & $4,5,8,9,10$ & $1,2,3,4,6,7,8,9$ & $4,8,9$ & \\
\hline 9 & $1,4,5,8,9,10$ & $1,2,3,4,6,7,8,9$ & $1,4,8,9$ & \\
\hline 10 & 5,10 & $1,2,3,4,6,7,8,9,10$ & 10 & \\
\hline
\end{tabular}

After marking level to a barrier in Table 5, we eliminated that barrier. We iterated this procedure till each of barrier obtained at least one level. A total of six iterations were performed in developing the ISM based model for the barriers of m-commerce adoption by SMEs in the UK. Table 6 presents a barrier or the list of barriers at each iteration by removing the corresponding element(s) i.e. $\mathrm{P}(\mathrm{i})$ from the previous step and identifying the 
new element(s) by matching the reachability set (i.e. R(i)) with antecedent set (i.e. R(Pi) \& $\mathrm{A}(\mathrm{Pi}))$ in the next iteration.

Table 6. Levels for barriers of m-commerce adoption in SMEs in the UK

\begin{tabular}{|c|c|c|}
\hline Iteration & Level\# & Barriers of m-commerce adoption in SMEs in the UK \\
\hline $1^{\text {st }}$ & I & - $\quad$ Lack of customer trust and confidence (C5) \\
\hline $2^{\text {nd }}$ & II & - $\quad$ Privacy and security issues (C10) \\
\hline $3^{\text {rd }}$ & III & $\begin{array}{ll}\text { - } & \text { Forced changes to business strategies (C4) } \\
\text { - } & \text { Lack of external pressure (C8) } \\
\text { - } & \text { Compatibility issues (C9) }\end{array}$ \\
\hline $4^{\text {th }}$ & IV & $\begin{array}{ll}\text { - } & \text { Perceived cost (C1) } \\
\text { - } & \text { Inconvenience of use (C7) }\end{array}$ \\
\hline $5^{\text {th }}$ & $\mathrm{V}$ & $\begin{array}{l}\text { - Lack of technology knowledge (C3) } \\
\text { - Unawareness (C6) }\end{array}$ \\
\hline $6^{\text {th }}$ & VI & - Perceived risk (C2) \\
\hline
\end{tabular}

\subsection{MICMAC analysis}

The main purpose of the MICMAC analysis is to understand the driving and dependence power of each variable within the ISM and to identify key enablers within the hierarchy of mcommerce barriers. Populating the driving and dependence powers within the MICMAC matrix is carried out by totalling the number of the figure ' 1 ' along each row and column of every variable, as shown in Table 12. The total of each row and column for each variable becomes the coordinates in which the variable is positioned on the diagram (Figure 2). The four quadrants of the MICMAC diagram specify the influence of the power and dependence aspects of the different relationships between the variables. In other words, which quadrant the variable is positioned indicates the extent of its power and dependence in relation to the other variables and how it fits in the ISM model. The four quadrants are:

Independent - defines variables that are of a weak dependence power but of high driving power and are quite often seen as key factors.

Dependent - defines variables that have a strong dependence barrier but weak driving power. They are usually variables that are heavily influenced by others.

Autonomous - defines variables with weak driving power and dependence power. They have very minimal influence or impact and maintain few links with other variables.

Linkage - defines variables with high driving power and high dependence power. They are deemed unstable as a result and any action taken involving these variables will likely cause a corresponding reaction, affecting itself and other variables. 


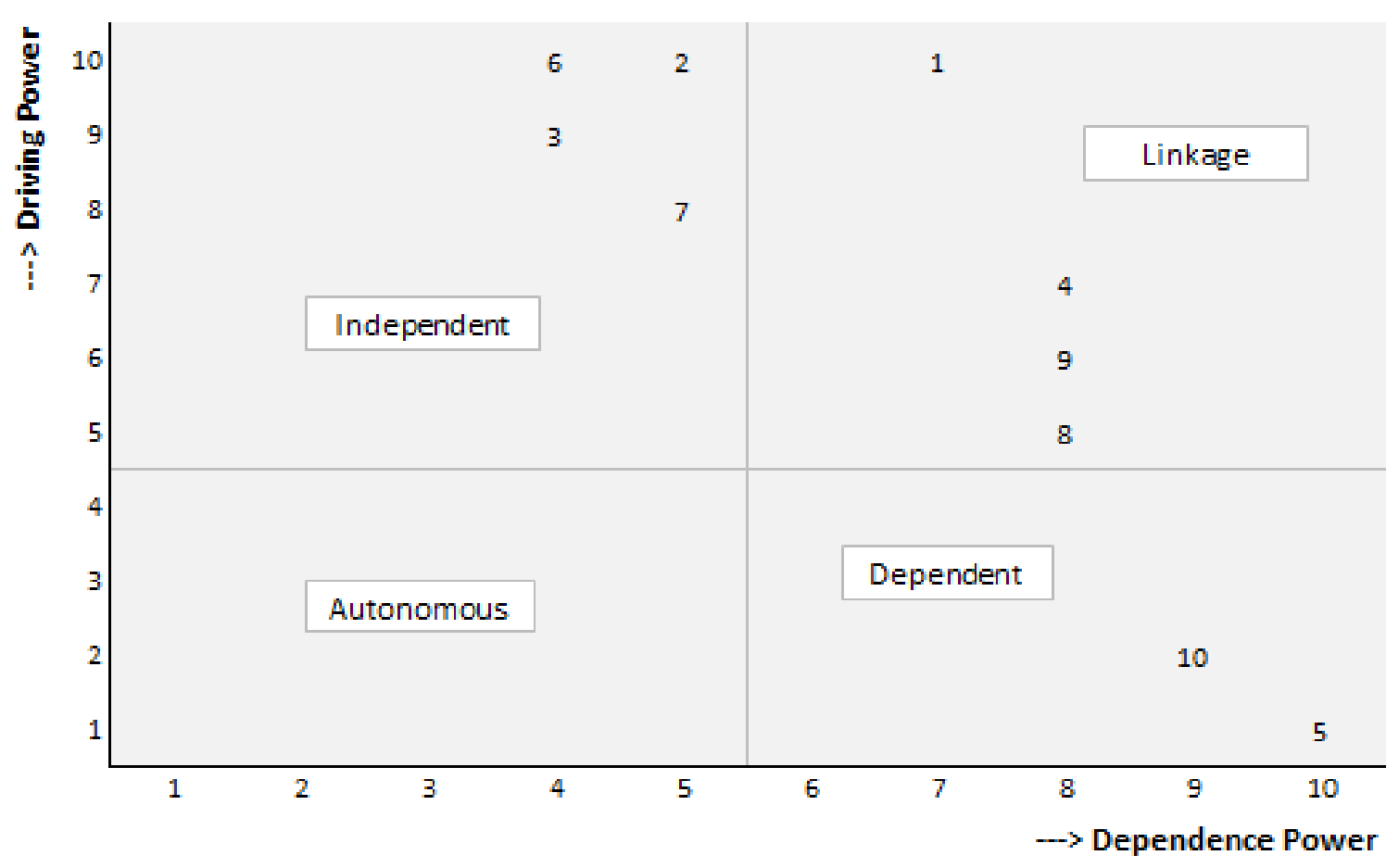

Figure 2. MICMAC diagram

The majority of variables in the MICMAC diagram are within the Independent and Linkage quadrants in the top half. This shows that the majority are of moderate to high driving power with high dependence power. This clustering indicates that there are a number of variables that driving a fewer number of more dependent variables and are therefore positioned in the middle ground of the ISM model. With that said, these variables, especially those within the Linkage quadrant are unstable and any action taken that involves them will have a corresponding reaction on the other variables. The main characteristic of these types of variables is that due to their nature and high number of interconnections any failings among them will have a knock-on effect and potential to cause failure among other variables.

The variables located in the Dependent quadrant are those variables that are heavily affected by the actions taken with regard to those situated in the Linkage quadrant. They do not have the driving power necessary to influence other variables and so are situated in the top layer model. There are no variables in the Autonomous quadrant showing there are no variables that have zero interconnections with the others in the MICMAC diagram. As a result it is fair to assume that all variables are connected in some way due to the levels of driving and dependence power that they possess.

\subsection{ISM model}

The final stage of the ISM process is the model. This model or digraph represents the variables by visually portraying the relationships between them. Every individual variable is positioned in relation to their driving and dependence power calculated in the last few stages. The levels are associated with the four quadrants that are featured in the MICMAC diagram in Figure 2. There is no strict ruling as to which level represents which quadrant; rather it is a 
progressive model that takes into consideration the exact score of the variable with regard to its driving and dependence power found in the canonical form matrix in tables 11 and 12.

The top level of the digraph identifies just the one variable in 'Lack of customer trust and confidence' (5). The reason it sits at the top of the model is down to the fact it has maximum dependence power and minimal driving power. As a result, the variable depends heavily on the lower level variables in order to achieve any significance with regard to the affects it may have on SME managers.

The level down is also occupied by only one variable in the form of 'Privacy and security issues' (10). The nature of this variable is very similar to that of ' 5 '; however, the driving and dependence scores are not as extreme and therefore it does enough to drive the top layer while dependent enough to link with three other variables from the level below.

The third level is where the variables with strong links between themselves and other levels are contained. 'Forced changes to business strategy' (4), 'Lack of external pressure' (8) and 'Compatibility issues' (9) are all positioned in the Linkage quadrant of the MICMAC diagram, with identical dependence power and similar driving power. This means they are strong influencers of those variables they are connected to but at the same time are also greatly influenced by them.

The fourth layer, for the variables of middle ground status contains, 'Perceived cost' (1) and 'Inconvenience of use' (7). Although their driving and dependence power scores vary to some extent and they reside in different quadrants it is the nature in which they both rely and have an effect on other variables that groups them together. The fifth layer is similar in nature, containing two variables; however, their dependence score is lower, pushing them further down the levels. The two variables are, 'Lack of technology knowledge' (3) and 'Unawareness of benefits' (6). The final level contains only 'Perceived risk' (2). This is the single variable with a high driving power and moderately low dependence power that sits alone on the MICMC diagram. For this reason, it is featured in the bottom level as it lacks the connections with other variables that makes it dependent but possesses enough driving power to influence the level above.

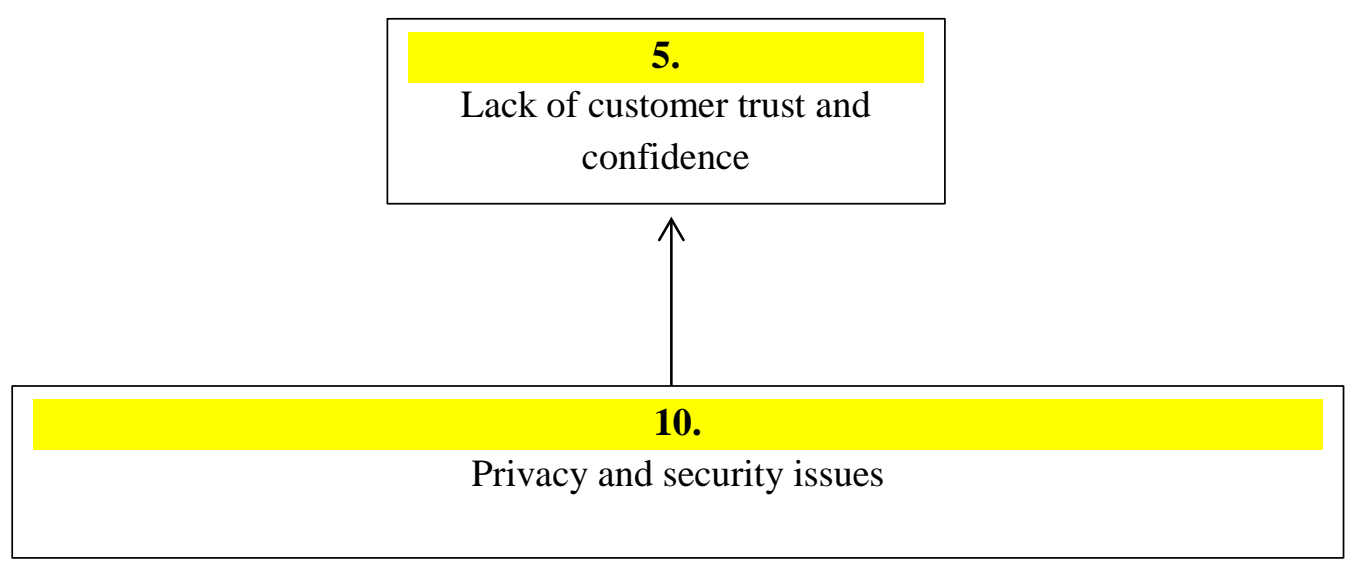

Level I 


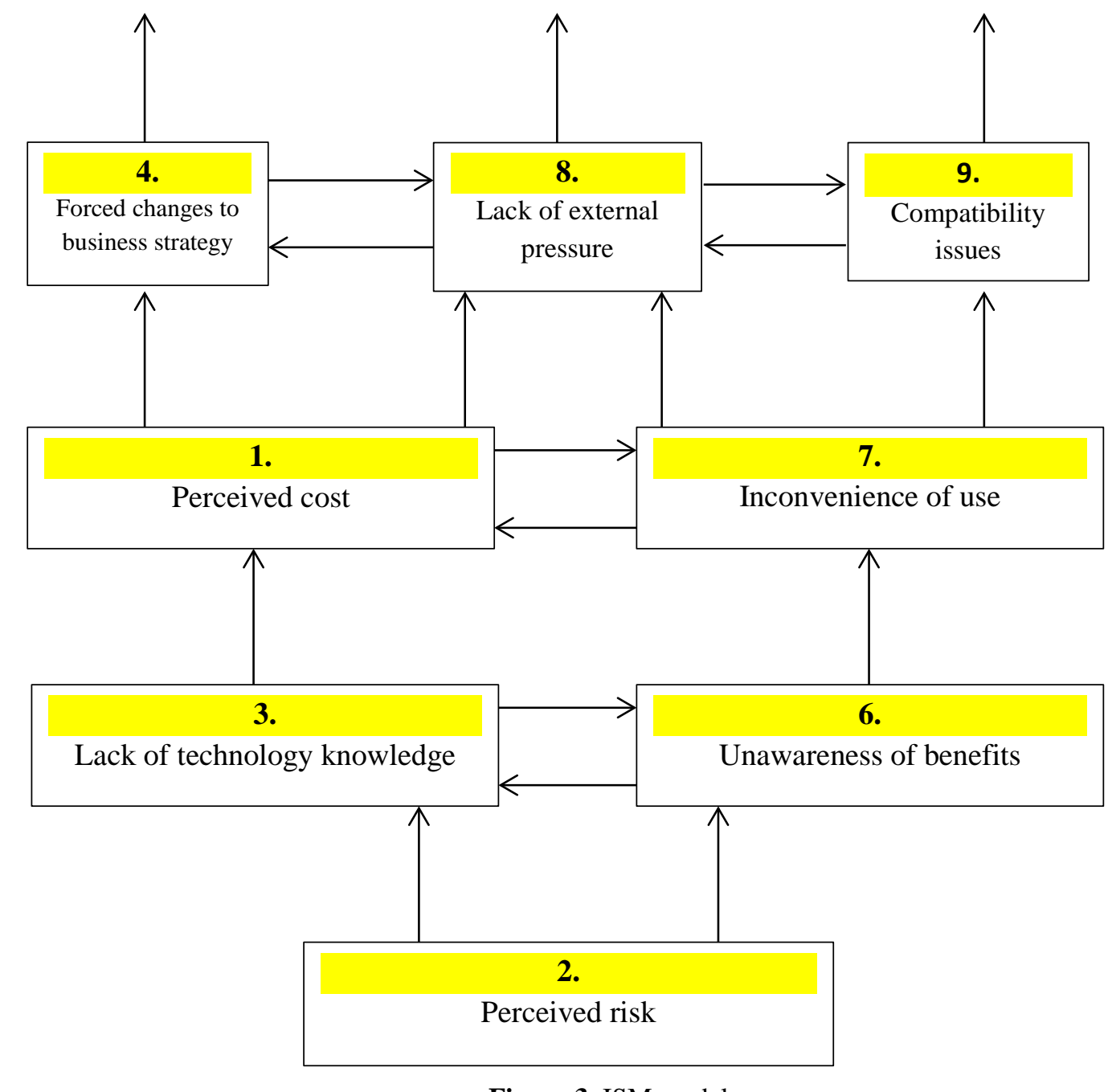

Level III

Level IV

Level V

Level VI

Figure 3. ISM model

\section{Discussion}

The key question for this study raises with reference to the results is: are there any patterns of barriers for m-commerce adoption by SMEs and can they be addressed and avoided by the top management of such enterprises? This study approached SME managers in order to gather their thoughts and opinions on the subject matter and to understand how they prioritise the barriers of adoption and if they identify the levels and interrelationships between them. These barriers were drawn from the literature and are a collection of unrelated barriers from previous research that did not focus specifically on their positioning and interrelationships. With the aid of industry specific experts and an in-depth analysis of the current literature, we have made an attempt to fill this research gap that has been made with the aim of educating and supporting SME managers.

This study has a number of contributions to theory. First, this research has compiled all relevant studies on m-commerce adoption in the SMEs context, reviewed and synthesised the literature to extract their barriers. Second, this is the first research of its type that has explored the barriers of m-commerce adoption and derived its framework using ISM for the SMEs in the context of the UK. Third, the MICMAC diagram also provides the nature of variables that 
clearly identifies their driving and dependence powers. This helps researchers more clearly understand the nature of variables in terms of them being more like an independent, mediating or dependent variable. Finally, the developed framework using ISM could help researchers in picking up the selected variables for empirically evaluating the proposed research model.

A large number of the barriers within m-commerce adoption have high levels of driving power and are positioned in the Independent and Linkage quadrants of the MICMAC diagram. As a result, they are characterised by their dependence on each other and their ability to influence other variables within the model. There are only two variables with a driving power lower than five. They are both positioned in the Dependent quadrant and score a high level of dependence power suggesting they rely heavily on other factors. The positioning of these variables within the MICMAC diagram and their formation in the final ISM model indicates a level of volatility that assumes if any action is taken on these variables, it will have a corresponding reaction on other variables. For example if an SME manager considered 'Forced changes to business strategy' (4) as a contributor to the prevention of adoption then other relating variables such as 'Lack of external pressure' (8) and 'Compatibility issues' (9) could potentially become an issue due to their close relationships within the Linkage quadrant. On the first and second level of the ISM model are 'Lack of customer trust and confidence' (5) and 'Privacy and security issues' (10) respectively exhibit high dependence power, hence they are positioned at the higher position in the ISM model. However it is their lower driving power that creates the sense of vulnerability as they rely on all other variables below them. The high position for factors such as 'Lack of customer trust and confidence' (5) and 'Privacy and security issues' (10) in the model suggests that these factors are heavily dependent on other factors that precede them. These factors are shown in the MICMAC analysis to exhibit maximum levels of dependency. This means that these factors are strongly impacted by other related factors in the ISM model and have been established by other research studies as the key barriers of m-commerce adoption in SMEs (Hughes et al., 2016).

A lack of customer trust and confidence is a significant barrier, as the customer creates the value of the whole concept of m-commerce. Without customers the infrastructure will become redundant and maintenance costs will prove to be an unprofitable expense. Siau \& Shen (2003) also conclude that trust is a continuous process which signifies the importance of overcoming the barrier. Vasileiadis (2014) believes customers are disappointed when online vendors use data on their current location and Internet habits to better market the offered products or services. The results of these studies indicate how a lack of customer trust and confidence is a key barrier in the prevention of m-commerce adoption and why it is represented at the top of the ISM model.

At Level V and Level VI, the more independent barriers are positioned, in the form of 'Perceived risk' (2), 'Lack of technology knowledge' (3) and 'Unawareness of benefits' (6). The MICMAC analysis identifies high levels of driving power for these variables, with lower levels of dependence power. For example, if an SME suffers from 'Inconvenience of use' (7), we can assume from the ISM analysis that it is likely that the effects of those variables with higher driving power are a cause. Two of the variables, 'Lack of knowledge' (3) and 'Unawareness of benefits' (6) are elements of uncertainty as they are based on unawareness 
and a lack of technology knowledge. Therefore it can be assumed that the variables based on uncertainty and a general lack of understanding form the basis of m-commerce adoption prevention and are key drivers. Estrin, Forman \& Garcia (2003) indicate how important it is for all personnel in the organisation to possess a certain level of technology knowledge. This aligns with the results of the ISM model as an integral barrier in terms of the effect it has on other variables.

The variable 'Perceived risk' (2), at Level IV, is identified as having a significant relationship with 'Lack of technology knowledge' (3) and 'Unawareness of benefits' (6) and acts as the single driving force behind them. Their interconnections at the driving end of the ISM model and possess high level of impact. The completed ISM model in the comparable study by Hughes, Dwivedi, Rana \& Simintiras (2016) exhibits a similar shape. The lower section of the model is populated by a few factors that drive a host of variables trigger a range of reactions due to the power they have through established interconnections. The factors are associated with information system failure and the nature of the study, specifically the use of ISM, is closely linked with the use of ISM in the barriers of m-commerce adoption in this study. 'Perceived risk' (2) as a key factor in affecting adoption intentions among SME managers is proven in the results to achieve a high level of influence over other variables. The level of risk associated with adoption will affect the significance of other related barriers that stem from it. If there is a level of high perceived risk then it is more likely other barriers will come into play as the manager looks to diminish the risk by evaluating other variables.

'Perceived risk' (2) is a key barrier that demonstrates how personal opinions of the concept of adoption can have a great significance on outcomes. The weight of risk perceptions is among different managers will vary, however, from the results it is clear that regardless of the significance placed upon the variable, it is still a major driving factor. The literature largely focuses on risk from the consumer perspective (Harris et al., 2016) however, Wurster (2014) concludes in their study that risk is not a one dimensional element and that it should not be viewed as an element itself but built up by various other factors. These conclusions support the analysis that risk is a driving factor that can have a great influence over connecting variables in the ISM model.

Directly linked to 'Perceived risk' (2) is 'Lack of technology knowledge' (3) and 'Unawareness of barriers' (6) in Level V. The two variables display a high rate of driving power and lower dependence power which position them lower down the model. Lacking the certain type of knowledge required and not being aware of the potential benefits in itself is a type of risk that managers of SME must avoid if they are to make a success of m-commerce adoption. It will be difficult to integrate m-commerce systems into the business without the necessary knowledge. These variables tie in heavily with 'Perceived risk' (2) which explains why they are closely linked with regard to the model and their MICMAC diagram scores. The concept that the variables are closely linked and are key barriers to adoption is rejected in the literature as Aburalob \& Kang (2015) conclude that uncertainty has a significantly positive impact to resistance of adoption and that perceived risk is bought about by uncertainty of benefits. M-commerce research of this nature is difficult to come by so these findings are from an e-commerce adoption study but it does not take away the fact that these variables are strongly linked. 
Level IV can be justified as another extension of the previous level. 'Perceived cost' (1) and 'Inconvenience of use' (7), although positioned in different quadrants of the MICMAC diagram, they are closely related in terms of both their driving and dependence power. Each one strongly influences the variables in the above level while their own behaviour is influenced by the level below. The literature suggests that price is one of the key factors that affects the adoption decision (Bouwman, Carlsson, Molina-Castillo \& Walden, 2007; Pagani, 2004). However, the results indicate that price alone does not determine the choices made by SME managers. The dependence level of the variable insinuates that other variables must have influence and are causal factors; moreover, cost will become an issue only after risk is assessed. If cost is the prevailing issue then it is likely that perceived risk could be an extended concern because of its strong driving power and interconnections.

The other variable in this level is 'Inconvenience of use' (7). The inconvenience of use is defined by how well the proposed m-commerce infrastructure integrates with the already present business processes of the SME. As it maintains similar characteristics of the variable 'Perceived cost' (1) with regard to driving and dependence power, it is highly likely that one will affect the other and vice versa. It would only become clear that the technology would become an inconvenience after a certain amount of research is conducted, by that time a risk analysis should have been conducted.

Level III hosts the grouping of variables within the Linkage quadrant. As previously discussed these variables are defined by their dependence on each other and the influence they have on those variables they are connected with. In the instance that one of these variables is the cause of an issue within the adoption process then other variables could become issues on the project.

The other variable in this level is 'Lack of external pressure' (8). This refers to the extent of outside pressure from customers and other stakeholders that would prefer to see the SME adopt more modern technologies. In this particular case, the barrier is suggesting that there is not a substantial amount of pressure on the SME to adopt such technologies and as such the manager may decide against adopting. The level of driving and dependence power of this variable places it in the Linkage quadrant along with the other two variables in this level. From the model it is clear to see the links between the variable (8) and 'Perceived cost' (1) and 'Inconvenience of use' (7) from the level below. From a mangers perspective this link is vital in understanding just how the barriers relate and how together they create a substantial block in the adoption process. The level of significance of this variable depends on the level of significance of those around it. 'Lack of external pressure' (8) may become an issue in isolation, where by itself its effects will determine whether adoption is carried out. Taylor \& Murphy (2004) agree with this notion and raise an interesting point when explaining that SMEs are more likely to occupy small market niches where global connectivity through wireless devices is not a necessity and customer are not pressurising the business to take action.

Level II contains only one variable, 'Privacy and security issues' (10). The level of driving power is very low, while the dependency power is very high, placing it in the Dependent quadrant. As the ISM method suggests, this variable is greatly influenced by other variables below in the model and is cited frequently within the literature. Ghosh \& Swaminatha (2001) point out that the penetration of malicious code is probably the most significant risk to m- 
commerce while Prakash \& Balachandra (2015) state a high level of importance must be given to the integrity and security of the information on its journey through wireless networks. These examples of literature together signify the importance of 'Privacy \& security issues' (10) that can be regarded as a key barrier of adoption. Despite the attention it receives from academics and the notion of its importance as a key barrier, it remains as a variable of high dependence power with regard to the MICMAC diagram, meaning its influence on the adoption process is influenced by the actions of other variables. From the manager's perspective, the privacy and security issues may well be a secondary thought or concern, with higher driving power that must be addressed beforehand. Alternatively, if an SME manager pinpointed this variable as the main factor in adoption prevention, then because of its high dependence power, it is highly likely that other variables with links to this factor will become an issue. Although dependence power is high, there is an element of driving power which is the cause of the direct link between itself and the last level in the ISM model.

The final level of the ISM model (Level I), is represented by a single variable. 'Lack of customer trust and confidence' (5) in the MICMAC diagram has the minimum driving power score and the maximum dependence power score, which positions it in the Dependent quadrant and at the top of the ISM model. Studies that directly analyse the effects of mcommerce interactivity on customer trust indicate that building relationships is crucial to gaining trust among customers. More specifically, to gain trust and confidence, interactivity between the SME and the customers must occur in order to build relationships. In other words, m-commerce must be in effect to understand the extent of customer trust and confidence. In the ISM model, the variable is represented as having the highest level of dependence power and is therefore more likely to become an issue if variables before are to come into effect. There is an obvious link between 'Privacy and security issues' (10) and 'Lack of customer trust and confidence' (5) that suggests customers will lack the motivation to use the technology for commercial purposes if the SME cannot guarantee a safe, secure and private online experience.

\section{Conclusion, Limitations and Future Research}

The study has explored the various barriers that can prevent the adoption of m-commerce technology within SMEs in the UK. Through the use of ISM, a final model that categorises each barrier and represents the interconnections between them was provided to help SME managers and academics to understand the concept and become familiar with the relationships that can cause adoption failure. By utilising ISM this study was able to provide further insight and a contextualisation of the key relationships between barriers. These factors were then processed through the steps of the ISM methodology.

The findings highlight the unstable nature of variables in the context of their impact on each other, their relationships, and themselves. It proves the importance of analysing data as a collective entity rather than viewing the barriers in isolation. The MICMAC diagram in Figure 2 has identified the driving and dependence power of each variable and assigned them to a specific quadrant on the diagram. The resulting positioning of the variables suggests a high level of driving power is associated with the majority of variables. High driving power is related to high levels of influence over related factors. The levels at the top end of the ISM 
model (see Figure 3) are populated by those barriers with the highest level of dependency power, meaning they will be impacted if any of the related variables in the lower levels are subject to preventing adoption. This identifies how high level dependent barriers must be carefully monitored if there is an issue with high driving power barriers.

This study is not without limitations. This study is limited by its specific selection of mcommerce barriers in isolation from the literature review on the factors surrounding its critical success factors. The future research could extend the ISM approach to develop a framework of critical success factors of e-commerce adoption for SMEs. The questionnaire was completed by managers of SMEs in the UK only. This narrows the scope of results. If the study was to be conducted in multiple regions with varying levels of m-commerce usage and technological development then greater comparisons could be made and the results could be more extensive. Additionally, although the process followed in this study adheres to the steps as outlined in the ISM method and as such has an empirical element, the results have not been statistically validated. To validate the results, primary data must be collected for the barriers of m-commerce adoption used in the proposed framework. The researchers can select some more relevant variables suitable to their context and formulate and empirically test their corresponding items and validate the proposed research model and their performance (e.g. Alalwan et al., 2016, 2017; Baabdullah et al., 2019; Dwivedi et al., 2017b; Rana et al., 2016, 2017).

\section{References}

Abebe, M. (2014). Electronic commerce adoption, entrepreneurial orientation and small-and medium-sized enterprise (SME) performance. Journal of Small Business and Enterprise Development, 21(1), 100-116.

Abualrob, A. A. \& Kang, J. (2016). The barriers that hinder the adoption of e-commerce by small businesses: Unique hindrance in Palestine. Information Development, 32(5), 15281544.

Al-Muftah, H., Weerakkody, V., Rana, N.P., Sivarajah, U., \& Irani, Z. (2018). E-diplomacy Implementation: Exploring Causal Relationships Using Interpretive Structural Modelling. Government Information Quarterly, DOI: 10.1016/j.giq.2018.03.002.

Alalwan, A.A., Dwivedi, Y.K., \& Rana, N.P. (2017). Factors Influencing Adoption of Mobile Banking by Jordanian Bank Customers: Extending UTAUT2 with Trust. International Journal of Information Management, 37(3), 99-110.

Alalwan, A.A., Dwivedi, Y.K., Rana, N.P., \& Williams, M.D. (2016). Consumer adoption of mobile banking in Jordan: Examining the role of usefulness, ease of use, perceived risk and self-efficacy. Journal of Enterprise Information Management, 29(1), 118-139.

Alkhunaizan, A. \& Love, S. (2012). What drives mobile commerce? An empirical evaluation of the revised UTAUT model. International Journal of Management and Marketing Academy, 2(1), 82-99.

Anckar, B. \& D'incau, D. (2002). Value creation in mobile commerce: Findings from a consumer survey. Journal of Information Technology Theory and Application, 4(1), 43-64.

Baabdullah, A. M., Alalwan, A. A., Rana, N. P., Kizgin, H., \& Patil, P. (2019). Consumer use of mobile banking (M-Banking) in Saudi Arabia: Towards an integrated model. International Journal of Information Management, 44, 38-52. 
Bouwman, H., Carlsson, C., Molina-Castillo, F. J. \& Walden, P. (2007). Barriers and drivers in the adoption of current and future mobile services in Finland. Telematics and Informatics, 24(2), 145-160.

Chin, A. G., Harris, M. A., \& Brookshire, R. (2018). A bidirectional perspective of trust and risk in determining factors that influence mobile app installation. International Journal of Information Management, 39, 49-59.

Dahlberg, T., Guo, J. \& Ondrus, J. (2015). A critical review of mobile payment research. Electronic Commerce Research and Applications, 14(5), 265-284.

Djenouri, D., Khelladi, L. \& Badache, N. (2005). A survey of security issues in mobile ad hoc networks. IEEE Communications Surveys, 7(4), 2-28.

Dwivedi, Y.K., Janssen, M., Slade, E., Rana, N.P., Weerakkody, V., Millard, J., Hidders, A.J.H., \& Snijder, D. (2017a). Driving Innovation through Big Open Linked Data (BOLD): Exploring Antecedents using Interpretive Structural Modelling. Information Systems Frontiers, 19(2), 197-212.

Dwivedi, Y.K., Rana, N.P., Jeyaraj, A., Clement, M., \& Williams, M.D. (2017b). Reexamining the Unified Theory of Acceptance and Use of Technology (UTAUT): Towards a Revised Theoretical Model. Information Systems Frontiers, DOI: 10.1007/s10796-017-9774y.

Einav, L., Levin, J., Popov, I. \& Sundaresan, N. (2014). Growth, adoption, and use of mobile E-commerce. The American Economic Review, 104(5), 489-494.

Estrin, L., Foreman, J. T. \& Garcia-Miller, S. (2003). Overcoming barriers to technology adoption in small manufacturing enterprises (SMEs). Technical Report - Carnegie Mellon Software Engineering Institute, Pittsburgh, USA.

Fang, J., Zhao, Z., Wen, C., \& Wang, R. (2017). Design and performance attributes driving mobile travel application engagement. International Journal of Information Management, 37(4), 269-283.

Ghosh, A. K. \& Swaminatha, T. M. (2001). Software security and privacy risks in mobile ecommerce. Communications of the ACM, 44(2), 51-57.

Harris, M. A., Brookshire, R., \& Chin, A. G. (2016). Identifying factors influencing consumers' intent to install mobile applications. International Journal of Information Management, 36(3), 441-450.

Harris, P., Rettie, R. \& Cheung, C. K. (2005). Adoption and usage of m-commerce: A crosscultural comparison of Hong Kong and the United Kingdom. Journal of Electronic Commerce Research, 6(3), 210-224.

Hughes, D. L., Dwivedi, Y. K., Rana, N. P. \& Simintiras, A. C. (2016). Information systems project failure-analysis of causal links using interpretive structural modelling. Production Planning \& Control, 27(16), 1313-1333.

Hunaiti, Z., Masadeh, R., Mansour, M. \& Al-Nawafleh, A. (2009). Electronic commerce adoption barriers in small and medium-sized enterprises (SMEs) in developing countries: The case of Libya. IBIMA Business Review, 2(5), 37-45.

Hussain, A., Mkpojiogu, E. O. \& Kamal, F. M. (2016). A Systematic Review on Usability Evaluation Methods for M-Commerce Apps. Journal of Telecommunication, Electronic and Computer Engineering, 8(10), 29-34. 
Janssen, M., Rana, N. P., Slade, E., \& Dwivedi, Y. K. (2018). Trustworthiness of Digital Government Services: Deriving a comprehensive theory through Interpretive Structural Modelling. Public Management Review, 20(5), 647-671.

Jharkharia, S. \& Shankar, R. (2005). IT-enablement of supply chains: Understanding the barriers. Journal of Enterprise Information Management, 18(1), 11-27.

Kim, S. H. (2006). Impact of mobile-commerce: benefits, technological and strategic issues and implementation. Journal of Applied Sciences, 6(12), 2523-2531.

Kourouthanassis, P. E. \& Giaglis, G. M. (2012). Introduction to the special issue mobile commerce: the past, present, and future of mobile commerce research. International Journal of Electronic Commerce, 16(4), 5-18.

Kuehn, A. (2013). Cookies versus clams: Clashing tracking technologies and online privacy. Info, 15(6, 19-31.

Lane, M. S., Van Der Vyver, G., Delpachitra, S. \& Howard, S. (2004), An electronic commerce initiative in regional Sri Lanka: the vision for the central province electronic commerce portal, Doctoral dissertation, City University of Hong Kong.

Lee, T. (2005). The impact of perceptions of interactivity on customer trust and transaction intentions in mobile commerce. Journal of Electronic Commerce Research, 6(3), 165-180.

Liébana-Cabanillas, F., Marinković, V., \& Kalinić, Z. (2017). A SEM-neural network approach for predicting antecedents of m-commerce acceptance. International Journal of Information Management, 37(2), 14-24.

Lin, H. F. (2011). An empirical investigation of mobile banking adoption: The effect of innovation attributes and knowledge-based trust. International Journal of Information Management, 31(3), 252-260.

Looi, H. C. (2005). A model of factors influencing electronic commerce adoption among small and medium enterprises in Brunei Darussalam. International Journal of Information Technology and Management, 10(1), 72-87.

Mennecke, B. E. \& Strader, T. J. (2003), Mobile commerce: technology, theory, and applications. IGI Global, IRM Press.

Mishra, N., Singh, A., Rana, N. P., \& Dwivedi, Y. K. (2017). Interpretive Structural Modelling and Fuzzy MICMAC Approaches for Customer Centric Beef Supply Chain: Application of a Big Data Technique. Production Planning \& Control, 28(11-12), 945-963.

Ngai, E. W. \& Gunasekaran, A. (2007). A review for mobile commerce research and applications. Decision Support Systems, 43(1), 3-15.

Olatokun, W. \& Bankole, B. (2011). Factors influencing electronic business technologies adoption and use by small and medium scale enterprises (SMEs) in a Nigerian municipality. Journal of Internet Banking and Commerce, 16(3), 1-26.

Paavilainen, J. (2002). Mobile business strategies: understanding the technologies and opportunities. Pearson Education.

Pagani, M. (2004). Determinants of adoption of third generation mobile multimedia services. Journal of Interactive Marketing, 18(3), 46-59.

Pathan, A. S. K., Lee, H. W. \& Hong, C. S. (2006). Security in wireless sensor networks: issues and challenges. The 8th International Conference on Advanced Communication Technology, Phoenix Park, South Korea. 
Pracy, D. \& Cooper, J. (2000). Internet commerce adoption by small and medium sized enterprises in the Illawarra. In CollECTeR 2000 Conference Proceedings, December 2000, Brisbane, Australia.

Prakash, K. (2015). Security Issues and Challenges in Mobile Computing and MCommerce. International Journal of Computer Science and Engineering Survey, 6(2), 29-45.

Rahimi, M. R., Ren, J., Liu, C. H., Vasilakos, A. V. \& Venkatasubramanian, N. (2014). Mobile cloud computing: A survey, state of art and future directions. Mobile Networks and Applications, 19(2), 133-143.

Rana, N. P., Dwivedi, Y. K., Lal, B., Williams, M. D., and Clement, M. (2017). Citizens' Adoption of an Electronic Government System: Toward a Unified View. Information Systems Frontiers, 19(3), 549-568.

Rana, N. P., Dwivedi, Y. K., Williams, M. D., and Weerakkody, V. (2016). Adoption of Online Public Grievance Redressal System in India: Toward Developing a Unified View. Computers in Human Behavior, 59, 265-282.

Saguy, I. S. (2011). Paradigm shifts in academia and the food industry required to meet innovation challenges. Trends in Food Science \& Technology, 22(9), 467-475.

Scupola, A. (2003). The adoption of Internet commerce by SMEs in the south of Italy: An environmental, technological and organizational perspective. Journal of Global Information Technology Management, 6(1), 52-71.

Shao Yeh, Y. \& Li, Y. M. (2009). Building trust in m-commerce: Contributions from quality and satisfaction. Online Information Review, 33(6), 1066-1086.

Siau, K. \& Shen, Z. (2003). Building customer trust in mobile commerce. Communications of the ACM, 46(4), 91-94.

Siau, K., Ee-Peng, L. \& Shen, Z. (2001). Mobile commerce: promises, challenges, and research agenda. Journal of Database Management, 12(3), 4-13.

Singh, R. K., Garg, S. K. \& Deshmukh, S. G. (2007). Interpretive structural modelling of factors for improving competitiveness of SMEs. International Journal of Productivity and Quality Management, 2(4), 423-440.

Sissing, J., Dlamini, N. N. \& Johnston, K. (2017). Using m-commerce to achieve strategic objectives in South African retail organisations. Journal of Applied and Physical Sciences, 3(1), 7-16.

Sotiriadis, M. D. \& Van Zyl, C. (2013). Electronic word-of-mouth and online reviews in tourism services: The use of twitter by tourists. Electronic Commerce Research, 13(1), 103124.

Stead, B.A. \& Gilbert, J. (2001). Ethical issues in electronic commerce. Journal of Business Ethics, 34(2), 75-85.

Sumita, U. \& Yoshii, J. (2010). Enhancement of e-commerce via mobile accesses to the Internet. Electronic Commerce Research and Applications, 9(3), 217-227.

Taylor, M. \& Murphy, A. (2004). SMEs and e-business. Journal of Small Business and Enterprise Development, 11(3), 280-289.

Thong, J. Y. \& Yap, C. S. (1995). CEO characteristics, organizational characteristics and information technology adoption in small businesses. Omega, 23(4), 429-442.

Vasileiadis, A. (2014). Security concerns and trust in the adoption of m-commerce. Social Technologies, 4(1), 179-191. 
Vrechopoulos, A., Constantiou, I., Sideris, I., Doukidis, G. \& Mylonopoulos, N. (2003). The critical role of consumer behaviour research in mobile commerce. International Journal of Mobile Communications, 1(3), 239-340.

Warfield, J.N. (1974). Developing subsystem matrices in structural modelling. IEEE Transactions on Systems, Man, and Cybernetics, 1), 74-80.

Wu, J. H. \& Wang, S. C. (2005). What drives mobile commerce?: An empirical evaluation of the revised technology acceptance model. Information \& Management, 42(5), 719-729.

Wurster, A. (2014). Mobile Payment-Risks of a New Technology. FAIMA Business \& Management Journal, 2(3), 14-23.

Xiaojun, D., Junichi, I. \& Sho, H. (2004). Unique features of mobile commerce. Journal of Electronic Science and Technology, 2(3), 205-210.

Yadav, R., Sharma, S. K. \& Tarhini, A. (2016). A multi-analytical approach to understand and predict the mobile commerce adoption. Journal of Enterprise Information Management, 29(2), 222-237.

\section{Appendix [A] - Survey Questionnaire}

Section A-Please choose only one choice in each question as follows:

1. What is your professional qualification level?

(a) Graduate (b) Postgraduate (c) Doctorate (d) If any other, please specify

2. What is your work experience?

(a) $<5$ years (b) 5-10 years (c) 11-15 years (d) 16-20 years (e) $>20$ years

3. What is the size of your organization?

(a) Less than 50 Employees (b) 51 to 250 Employees (c) More than 250 Employees

4. How will you classify your sector?

(a) Private sector (b) Public sector (c) Multinational corporation (d) Regulatory bodies (e) If any other, please specify

5. What is the approximate annual turnover of your organization (In thousand pounds)?

(a) $<=50$ (b) $50-100$ (c) $101-110$ (d) $111-130$ (e) $131-150$ (f) $>150$

Section B - Significance of the Barriers of M-Commerce Adoption in SMEs

6. Rate the following m-commerce adoption barriers on a 5-point Likert scale (1-not significant, 2somewhat significant, 3-significant, 4-very significant and 5-extremely significant) (Please choose only ONE in each row).

\begin{tabular}{|l|l|l|l|l|l|l|}
\hline \multirow{2}{*}{ SL } & \multirow{2}{*}{ M-Commerce Adoption Barriers } & \multicolumn{5}{|c|}{ Rating } \\
\hline & & $\mathbf{1}$ & $\mathbf{2}$ & $\mathbf{3}$ & $\mathbf{4}$ & $\mathbf{5}$ \\
\hline 1. & Perceived cost & & & & & \\
\hline 2. & Perceived risk & & & & & \\
\hline 3. & Lack of technology knowledge & & & & & \\
\hline 4. & Forced changes to business strategy & & & & \\
\hline 5. & Lack of customer trust and confidence & & & & \\
\hline 6. & Unawareness of benefits & & & & & \\
\hline 7. & Inconvenience of use & & & & \\
\hline 8. & Lack of external pressure & & & & & \\
\hline 9. & Compatibility issues & & & & & \\
\hline 10. & Privacy and security issues & & & & & \\
\hline
\end{tabular}

Section C - Contextual relationships between the m-commerce adoption barriers in SMEs

After finalizing the key m-commerce adoption barriers, the contextual relationships among them are 
formed. To represent these contextual relationships, a SSIM matrix is constructed (for which the entries in Table I are to be filled). The following four symbols are used (for filling the entries in Table I) indicating the direction of interaction between two challenges to mobile commerce adoption from and SME perspective (say, i and $\mathbf{j}$ ). V - Barrier $\mathbf{i}$ helps achieve or influences barrier $\mathbf{j}$, A - Barrier $\mathbf{j}$ helps achieve or influences barrier $\mathbf{i}, \mathrm{X}$ - Barriers $\mathbf{i}$ and $\mathbf{j}$ help achieve or influence each other and $\mathrm{O}$ Barriers $\mathbf{i}$ and $\mathbf{j}$ are unrelated

For example [1] if you think that only Variable $i=1$ i.e. 'Perceived cost' influences Variable $\mathrm{j}=2$ i.e. 'Perceived risk' then insert the symbol ' $V$ ' for $i=1$ and $j=2$. [2] If you think that only $j=2$ influences $i=1$ then insert symbol ' $A$ ' for $i=1$ and $j=2$. [3] If you think that both variables $i=1$ and $j=2$ influence each other, then update the cell with $i=1$ and $j=2$ with symbol ' $X$ ', or [4] If you think that both variables with $i=1$ and $j=2$ are unrelated to each other, then update the cell with $i=1$ and $j=2$ with symbol ' $O$ '. Please do this exercise for all the cells indicated in Table I and refer Table 1 for the definition of the selected barriers in the text above.

Table I. Relationship matrix for the barriers of mobile commerce adoption in SMEs

\begin{tabular}{|c|c|c|c|c|c|c|c|c|c|}
\hline$i^{j}$ & 10 & 9 & 8 & 7 & 6 & 5 & 4 & 3 & 2 \\
\hline 1 & & & & & & & & & \\
\hline 2 & & & & & & & & & \\
\hline 3 & & & & & & & & & \\
\hline 4 & & & & & & & & & \\
\hline 5 & & & & & & & & & \\
\hline 6 & & & & & & & & & \\
\hline 7 & & & & & & & & & \\
\hline 8 & & & & & & & & & \\
\hline 9 & & & & & & & & & \\
\hline
\end{tabular}

[1] Perceived cost [2] Perceived risk [3] Lack of technology knowledge [4] Forced changes to business strategy [5] Lack of customer trust and confidence [6] Unawareness of benefits [7] Inconvenience of use [8] Lack of external pressure [9] Compatibility issues [10] Privacy and security issues 